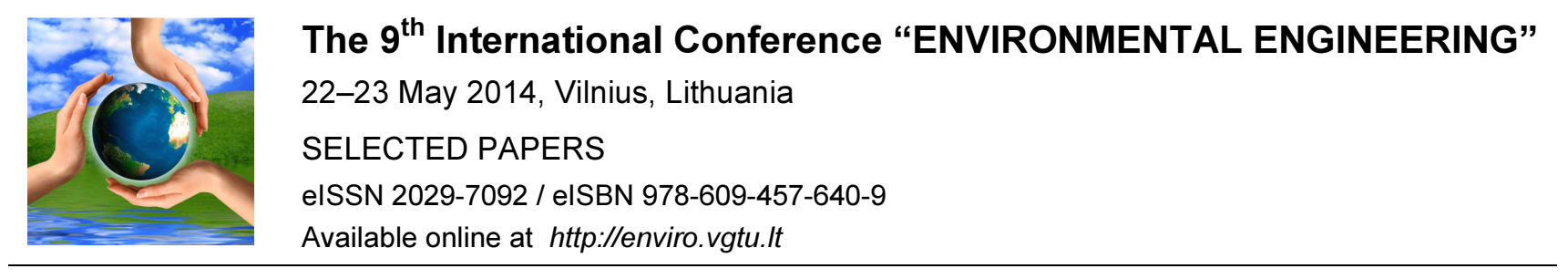

Section: Environmental protection

\title{
Assessment of general toxicity of the selected industrial wastes on the basis of the analysis of the total metals concentration
}

\author{
Terese Rauckyte-Żak ${ }^{\mathrm{a}}$, Alfredas Laurinavičius ${ }^{\mathrm{b}}$ \\ ${ }^{a}$ Department of Chemical Technology and Engineering, University of Technology and Life Sciences, \\ 3 Seminaryjna Street, 85-326 Bydgoszcz, Poland \\ ${ }^{b}$ Faculty of Environmental Engineering, Vilnius Gediminas Technical University, Sauletekio al. 11, LT-10223 Vilnius, Lithuania
}

\begin{abstract}
This paper presents a procedure to determine total toxicity of the selected waste material from scrap mobile phones and their components. The assessment is based on literature data of quantitative analyses of heavy metals ( $\mathrm{Ag}, \mathrm{As}, \mathrm{Ba}, \mathrm{Cd}, \mathrm{Co}, \mathrm{Cr}, \mathrm{Cu}, \mathrm{Hg}, \mathrm{Ni}, \mathrm{Pb}, \mathrm{Se}$ and $\mathrm{Zn}$ ) in compliance with the TTLC (Total Threshold Limit Concentration) and TCLP (Toxicity Characteristic Leaching Procedure) procedures. Coefficients for toxic criteria equations have been selected on the basis of limiting and standardizing TTLC and TCLP values. The calculated total toxicity value on the basis of the metals content was also verified by comparison with the sum of limited and standard values. The final classification of the waste material total toxicity was found to be a function of determinable concentration levels in the mass of waste material (TTLC criterion) and leachable forms of metals (TCLP criterion).
\end{abstract}

Keywords: total toxicity assessment of electronic wastes; TTLC and TCLP procedures.

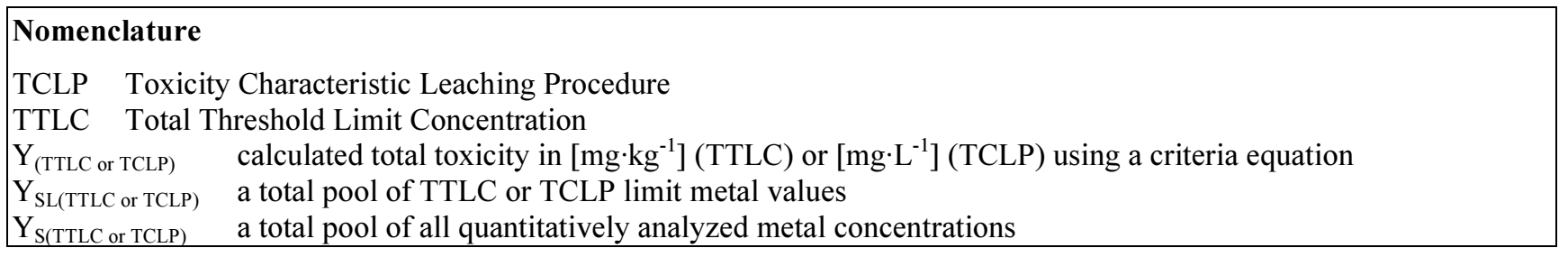

\section{Introduction}

The estimation of toxicity may be carried out i.a. with the use of three methods: TTLC (Total Threshold Limit Concentration), STLC (Soluble Threshold Limit Concentration) and TCLP (Toxicity Characteristic Leaching Procedure) [1]. Whereas TTLC and STLC methods are regulated in detail by California Code of Regulations and used mainly to characterize hazardous wastes [2], the TCLP method is based on the US federal law: EPA [3,4]. The methods mentioned consist in quantitative determinations of organic analytes and metals [5]. The analytical origin of the latter is an estimated simulation of the conditions on a hypothetical landfill, where different kinds of rainwater can migrate to reach the groundwater level, transporting pools of dissolved and analytically determinable components [6]. The TTLC method allows to determine the total content of the selected, criteria components in the sample mass of the tested wastes basing on the EPA procedures [7]. When a component determined quantitatively exceeds the value of allowable limit for TTLC procedure, the tested waste is qualified as hazardous and its final classification code depends on the component which exceeded its allowable limit expressed in $\mathrm{mg} \cdot \mathrm{kg}^{-1}$ [8]. The TCLP method classifies a given waste material as hazardous when the highest allowable limit for the total toxicity of leachable forms exceeded at least one of the group of components analytically determinable and expressed in $\mathrm{mg} \cdot \mathrm{L}^{-1}$ [9]. The aim of this study was the assessment and comparison of the total toxicities for the electronic waste material according to the criteria of TTLC and TCLP methods on the basis of analytically determined contents of metals.

Corresponding author: Terese Rauckyte-Żak. E-mail address: terra@utp.edu.pl

http://dx.doi.org/10.3846/enviro.2014.049

(C) 2014 The Authors. Published by VGTU Press. This is an open-access article distributed under the terms of the Creative Commons Attribution License, which permits unrestricted use, distribution, and reproduction in any medium, provided the original author and source are credited. 


\section{Computational Part}

Basing on the known metal concentrations (the presented example includes: $\mathrm{Ag}, \mathrm{As}, \mathrm{Ba}, \mathrm{Cd}, \mathrm{Co}, \mathrm{Cr}, \mathrm{Cu}, \mathrm{Hg}, \mathrm{Ni}, \mathrm{Pb}, \mathrm{Se}$ and $\mathrm{Zn}$ ) for selected electronic waste materials - the worn-out elements of mobile telephones, the total toxicity $\mathrm{Y}_{\text {(TTLC or TCLP) }}$ in accordance with TTLC and TCLP criteria was calculated using a criteria equation in the following form (1) [10,11]:

$$
\mathrm{Y}_{(\mathrm{TTLC} \text { or TCLP) }}=\mathrm{a} \cdot \mathrm{X}_{\mathrm{M}(\mathrm{a})}+\mathrm{b} \cdot \mathrm{X}_{\mathrm{M}(\mathrm{b})}+\mathrm{c} \cdot \mathrm{X}_{\mathrm{M}(\mathrm{c})}+\ldots+\mathrm{n} \cdot \mathrm{X}_{\mathrm{M}(\mathrm{n})},
$$

where:

$\mathrm{Y}_{(\mathrm{TTLC}}$ or TCLP) - total toxicity in $\left[\mathrm{mg} \cdot \mathrm{kg}^{-1}\right](\mathrm{TTLC})$ or $\left[\mathrm{mg} \cdot \mathrm{L}^{-1}\right](\mathrm{TCLP})$,

$\mathrm{X}_{\mathrm{M}(\mathrm{a})}, \ldots \mathrm{X}_{\mathrm{M}(\mathrm{n})}-$ metal concentrations $\left(\mathrm{M}_{(\mathrm{a})}, \ldots \mathrm{M}_{(\mathrm{n})}\right)$ determined in compliance with the procedures for TTLC and TCLP in waste samples (basing on literature data $[7,12,13]$ ),

$\mathrm{a}, \mathrm{b}, \mathrm{c}, \ldots \mathrm{n}$ - coefficients determined on the basis of criteria values of allowable limits defined in TTLC or TCLP procedures (determined using literature data [14] and listed in Table 1).

\subsection{Calculation principle}

Coefficients $(a-n)$ of the criteria equation (1) are established in such a way that their sum is a value of one $(a+\ldots+n=1)$ regardless of a number of metals and limit concentrations assumed for them $\left(\mathrm{LX}_{\mathrm{M}(\mathrm{n})}\right)$. For the needs of waste assessment, on the basis of the obtained analytical results from the TTLC procedure, limit values of the criteria concentrations of metals $\left(\mathrm{LX}_{\mathrm{M}(\mathrm{n})}\right)$ determined in the mass of waste material for particular analyzed metals $\left(\mathrm{LX}_{\mathrm{M}(\mathrm{a})}-\mathrm{LX}_{\mathrm{M}(\mathrm{n})}\right)$ are summed as first; the coefficient $\left(\mathrm{n}_{(\mathrm{TTLC})}\right)$ of metal $\left(\mathrm{M}_{(\mathrm{n})}\right)$ is calculated from the level of mass fraction of the metal limit concentration $\left(\mathrm{LX}_{\mathrm{M}(\mathrm{n})}\right)$ with reference to a total pool of limit values of all quantitatively analyzed metal concentrations $\left(\sum\left(\mathrm{LX}_{\mathrm{M}(\mathrm{a})(\mathrm{TTLC})}+\ldots+\right.\right.$ $\left.\mathrm{LX}_{\mathrm{M}(\mathrm{n})(\mathrm{TTLC})}\right)=\mathrm{Y}_{\mathrm{SL}(\mathrm{TTLC})}$ ). Consequently, the coefficient $\mathrm{n}$ (for metal $\left(\mathrm{M}_{(\mathrm{n})}\right)$ ) for the assessment on the basis of the results achieved from the TTLC procedure shall be determined from the following equation (2):

$$
\mathrm{n}_{\text {(TTLC) }}=\frac{\mathrm{LX}_{\mathrm{M}(\mathrm{n})(\mathrm{TTLC})}}{\sum_{\mathrm{n}=1}^{\mathrm{n}}\left(\mathrm{LX}_{\mathrm{M}(\mathrm{a})(\mathrm{TTLC})}+\ldots+\mathrm{LX}_{\mathrm{M}(\mathrm{n})(\mathrm{TTLC})}\right.}
$$

According to a criterion of TCLP procedure, the proceedings to determine the coefficients $\mathrm{n}_{(\mathrm{TCLP})}$ and the limiting level of $\mathrm{Y}_{\mathrm{SL} \text { (TCLP) }}$ parameter is analogous, except for the limit concentrations of leachable forms of metals in the tested eluate are considered (Table 1).

\begin{tabular}{|c|c|c|c|c|c|}
\hline No. & $\begin{array}{l}\text { Metal } \\
\left(\mathrm{M}_{(\mathrm{n})}\right)\end{array}$ & $\begin{array}{l}\text { Limit TTLC } \\
{\left[\mathrm{mg} \cdot \mathrm{kg}^{-1}\right]^{\mathrm{a})}}\end{array}$ & $\begin{array}{l}\text { Coefficient } \\
\mathrm{n}_{\text {(TTLC) }} \text { () }\end{array}$ & $\begin{array}{l}\text { Limit TCLP } \\
{\left[\mathrm{mg} \cdot \mathrm{L}^{-1}\right]^{\mathrm{b})}}\end{array}$ & $\begin{array}{l}\text { Coefficient } \\
\mathrm{n}_{(\mathrm{TCLP})}{ }^{\mathrm{c})}\end{array}$ \\
\hline 1 & Silver (Ag) & 500 & 0.0155 & 5 & 0.0101 \\
\hline 2 & Arsenic (As) & 500 & 0.0155 & 5 & 0.0101 \\
\hline 3 & Barium (Ba) & 10000 & 0.3104 & 100 & 0.2011 \\
\hline 4 & Cadmium $(\mathrm{Cd})$ & 100 & 0.0031 & 1 & 0.0020 \\
\hline 5 & Cobalt $(\mathrm{Co})$ & 8000 & 0.2483 & 80 & 0.1609 \\
\hline 6 & Chromium (Cr) & 2500 & 0.0776 & 5 & 0.0101 \\
\hline 7 & Copper $(\mathrm{Cu})$ & 2500 & 0.0776 & 25 & 0.0503 \\
\hline 8 & Mercury (Hg) & 20 & 0.0006 & 0.2 & 0.0004 \\
\hline 9 & Nickel (Ni) & 2000 & 0.0621 & 20 & 0.0402 \\
\hline 10 & Lead $(\mathrm{Pb})$ & 1000 & 0.0310 & 5 & 0.0101 \\
\hline 11 & Selenium $(\mathrm{Se})$ & 100 & 0.0031 & 1 & 0.0020 \\
\hline 12 & Zinc (Zn) & 5000 & 0.1552 & 250 & 0.5028 \\
\hline
\end{tabular}

Table 1. Criterial, limited concentrations of metals acc. to the procedures: TTLC and TCLP and determined toxicity coefficients

where: detailed descriptions of procedures and levels of limited concentrations are given in:

a) U.S. Environmental Protection Agency. Test Methods for Evaluating Solid Waste: Method 3050B-Acid Digestion of Sediments, Sludges, and Soils; EPA SW-846; Washington, DC, 1996; 12pp; accessed October 30, 2006, http://www.epa.gov/SW-846/pdfs/3050b.pdf;

b) US EPA. Method 1311: Toxicity Characteristic Leaching Procedure; Washington, DC, 1992; accessed online October 30, 2006, http://www.epa.gov/sw846/pdfs/1311.pdf;

${ }^{c}$ For specified group of analysed metals $\left(\mathrm{M}_{(\mathrm{n})}\right)$, the limit values $\left(\mathrm{Y}_{\mathrm{SL}}\right)$ are as follows: $\mathrm{Y}_{\mathrm{SL}(\mathrm{TTLC})}=32220\left[\mathrm{mg} \cdot \mathrm{kg}^{-1}\right]$ and $\mathrm{Y}_{\mathrm{SL}(\mathrm{TCLP})}=497.2\left[\mathrm{mg} \cdot \mathrm{L}^{-1}\right]$.

\subsection{Example}

For known concentrations of metals ( $\mathrm{Ag}, \mathrm{As}, \mathrm{Ba}, \mathrm{Cd}, \mathrm{Cr}, \mathrm{Co}, \mathrm{Cu}, \mathrm{Hg}, \mathrm{Ni}, \mathrm{Pb}, \mathrm{Se}$ and $\mathrm{Zn}$ ), the criteria limits $\left(\mathrm{Y}_{\mathrm{SL}(\mathrm{TTLC})}\right)$ and $\left(\mathrm{Y}_{\mathrm{SL}(\mathrm{TCLP})}\right)$ (based on limited levels of concentrations shown in Table 1) are respectively: $\mathrm{Y}_{\mathrm{SL}(\mathrm{TTLC})}=32220.0\left[\mathrm{mg} \cdot \mathrm{kg}^{-1}\right]$ and 
$\mathrm{Y}_{\mathrm{SL} \text { (TCLP) }}=497.2\left[\mathrm{mg} \cdot \mathrm{L}^{-1}\right]$. In the case of actual waste material: the worn-out elements of mobile telephones (Table 2) (on the basis of average concentrations of metals in 34 waste mobile telephone units - the analytical data were taken from the study [7]), the following values are obtained: $\mathrm{Y}_{(\mathrm{TTLC})}=20154.0\left[\mathrm{mg} \cdot \mathrm{kg}^{-1}\right]\left(\mathrm{Y}_{\mathrm{SL} \text { (TTLC) }}=32220.0\left[\mathrm{mg} \cdot \mathrm{kg}^{-1}\right]\right) \mathrm{and}_{(\mathrm{TCLP})}=$ $5.5\left[\mathrm{mg} \cdot \mathrm{L}^{-1}\right]\left(\mathrm{Y}_{\mathrm{SL}(\mathrm{TCLP})}=122.2\left[\mathrm{mg} \cdot \mathrm{L}^{-1}\right]\right)$. The assessed waste material can be classified by comparing the values $\mathrm{Y}_{(\mathrm{TTLC})}$ and $Y_{(T C L P)}$ with reference to the values limiting the total toxicity of $Y_{S L(T T L C)}$ and $Y_{S L(T C L P)}$. If the terms $Y_{(T T L C)}>Y_{\text {SL(TTLC) }}$ and/or $\mathrm{Y}_{(\mathrm{TCLP})}>\mathrm{Y}_{\mathrm{SL}(\mathrm{TCLP})}$ are fulfilled, the waste material fulfils toxic criterion. For reverse cases, the waste material is classified as non-toxic in accordance with the TTLC or TCLP criteria. For the considered calculation, the achieved classification is respectively:

a) In compliance with TTLC criterion:

$\mathrm{Y}_{\text {(TTLC) }}\left(20154.0\left[\mathrm{mg} \cdot \mathrm{kg}^{-1}\right]\right)<\mathrm{Y}_{\mathrm{SL}(\mathrm{TTLC})}\left(32220.0\left[\mathrm{mg} \cdot \mathrm{kg}^{-1}\right]\right)$ - non-toxic waste material;

b) In compliance with TCLP criterion:

$\mathrm{Y}_{\text {(TCLP) }}\left(5.5\left[\mathrm{mg} \cdot \mathrm{L}^{-1}\right]\right)<\mathrm{Y}_{\mathrm{SL}(\mathrm{TCLP})}\left(122.2\left[\mathrm{mg} \cdot \mathrm{L}^{-1}\right]\right)$ - non-toxic waste material.

The verification procedure $\left(\mathrm{Y}_{\mathrm{S}(\mathrm{TTLC})}\right.$ and/or $\left.\mathrm{Y}_{\mathrm{S}(\mathrm{TCLP})}\right)$ consists in comparing the sums of concentrations of the determined metals $\left(\mathrm{Y}_{\mathrm{S}(\mathrm{TTLC} \text { or TCLP) }}\right)$ for the assessed waste material with the sums of limited concentrations ( $\mathrm{Y}_{\mathrm{SL} \text { (TTLC or TCLP) }}$ ) according to the TTLC and TCLP criteria (for actual cases taken from literature, the determined parameters of toxicity are listed in Table 2 and Figures 1-3).

\section{Results and discussion}

A fast development of technological achievements brings customers world-wide new generations of cell telephones, tablets, smart phones, e-book readers and other more and more advanced electronic novelties. When their practical lifetime elapses, they will become a huge waste material classified as non-hazardous, hazardous or toxic wastes, according to the acknowledged criteria. Their final assessment and classification will decide about their further disposal: e.g. in recycling systems, physico-chemical or thermal treatment, or final waste disposal. Metal and organic compounds contained in the materials used to manufacture electronic goods such as: pigments, stabilisers, flame retardants, fillers etc. may appear to be significantly hazardous [15]. Analytical procedures used to determine the criteria analyte concentrations are of crucial importance. Generally, metals contained in polymer masses are determined with the use of techniques such as: AAS (atomic absorption spectrometry) [15-18], SS-GF AAS [19-21], inductively coupled plasma mass spectrometry (ICP-MS) [16, 17, 22], X-ray fluorescence spectrometry (XRFS) $[15,16,23,24]$. The analysis of metals contained in mobile telephone units in compliance with TTLC procedure is based on mineralizing test samples with acids: $\mathrm{HNO}_{3}$ or $\mathrm{HCl}$ in the presence of $\mathrm{H}_{2} \mathrm{O}_{2}$ and the later determination of the individual metals by AAS or ICP-AES, or ICP-MS [21,25-27].

The results for total toxicity of cell telephones and their subsets are presented in Tables 2-4 (the results of actual concentrations were taken from studies [7,12,13]). To estimate toxicity, the concentrations (min., mean and max.) of metals $\left(\mathrm{M}_{(\mathrm{n})}\right)$ applied in this study were determined with the following procedures: TTLC (Tables 2-4) and TCLP (Table 2). For final assessment and comparison of the established criteria parameter values, it is worth noticing that for $\mathrm{Ag}, \mathrm{As}, \mathrm{Ba}, \mathrm{Cd}$, $\mathrm{Co}, \mathrm{Cu}, \mathrm{Hg}, \mathrm{Ni}$ and $\mathrm{Se}$ the TTLC limit values of criteria concentrations are 100 times higher than the limit concentrations defined as criteria in the TCLP procedure. It is differently for zinc $(\mathrm{Zn}): 2$ times, lead $(\mathrm{Pb}): 200$ times, and for chrome $(\mathrm{Cr})$ : even 500 times. This fact is of significant importance for the values of the determined coefficients $\mathrm{n}_{(\mathrm{TTLC} \text { or TCLP) }}$ and $\mathrm{Y}_{\mathrm{SL}(\mathrm{TTLC}}$ or TCLP) (Table 1).

To compare parameters $Y_{(T T L)}$ or (TCLP) with $Y_{\mathrm{SL}(\mathrm{TTLC}) \text { or (TCLP) }}$ for the same metals $\left(\mathrm{M}_{(\mathrm{n})}\right)$ on the basis of actual concentrations identified for waste mobile telephones (the analytical data is taken from the study [7]), two variants for toxicity assessment were listed in Table 2 . The first group was established for the sum of all determined metals $\left(\mathrm{M}_{(\mathrm{n})}\right)$ and the other one (presented in brackets) - excluding $\mathrm{Co}, \mathrm{Cu}, \mathrm{Ni}$ and $\mathrm{Zn}$ (not given in the source material - not determined [7]). Based on actual quantitative analysis of metals, the presented example classifies waste material as non-toxic for all analytically determined ranges of concentrations when the parameters $\mathrm{Y}_{\text {(TCLP) }}$ and $\mathrm{Y}_{\mathrm{SL} \text { (TCLP) }}$ are assessed according to TCLP criteria (i.e. the concentrations of metals determined in $2.0 \mathrm{~L}$ of leached solution from $100.0 \mathrm{~g}$ of solid sample). The verification of calculations $\left(\mathrm{Y}_{\mathrm{S}(\mathrm{TCLP})}\right)$ confirms the assessment of non-toxic waste for minimum and average values of concentrations. However, the maximum values are qualified as toxic (Table 2). Using TTLC criteria, for which the concentrations refer to the mass of mineralized sample, the value of $\left(\mathrm{Y}_{(\mathrm{TTCL})}\right)$ parameter classifies the assessed waste material as non-toxic while the verification $\left(\mathrm{Y}_{\mathrm{S}(\mathrm{TTLC})}\right)$ as toxic for mean and maximum values of metal concentrations $\left(\mathrm{M}_{(\mathrm{n})}\right)$ (both variants of the evaluation). For minimum concentration ranges and considering all concentrations of all the analyzed metals $\left(\mathrm{M}_{(\mathrm{n})}\right)$, the divergent toxicity assessments are found. For the variant excluding the concentrations of $\mathrm{Cu}, \mathrm{Pb}, \mathrm{Ni}$ and $\mathrm{Zn}$ that exceed the limiting levels of the TTLC criterion, we achieve the assessment result which does not change the total toxicity $\mathrm{Y}_{(\mathrm{TTLC})}$ on the basis of equation (1) - the analyzed waste material is assessed as non-toxic. Analyzing actual metal concentrations determined in the wastes in accordance with TCLP procedure, it can be noticed that only $\mathrm{Pb}$ exceeds the threshold value - the limit TCLP criterion (by ca. 17 times) and the waste material can be assessed as hazardous with regard to that metal. If $\mathrm{Pb}_{(\mathrm{TCLP})}>100 \mathrm{mg} \cdot \mathrm{L}^{-1}$, there is a discrepancy between the classification using the parameters: $\mathrm{Y}_{(\mathrm{TCLP})}$ and

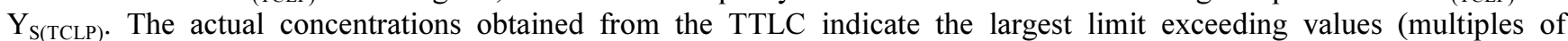
allowable concentration limits) for: copper (Cu) (ca. 81 times), lead (Pb) (ca.10), nickel (Ni) (ca. 5) and zinc ( $\mathrm{Zn})$ (ca. 2). According to the U.S. environmental legislation (EPA), four hazardous waste codes may be assigned for such waste material. However, it should be noticed that in that particular case a significant impact on the value of parameter $\mathrm{Y}_{(\mathrm{TCLP})}$ has 
the lack of the determination for $\mathrm{Cu}, \mathrm{Ni}, \mathrm{Zn}$ concentrations (in the context of the TCLP in accordance with the source material [7]). Lead $(\mathrm{Pb})$ is the main metal which concentration affects the divergence while making classification based on

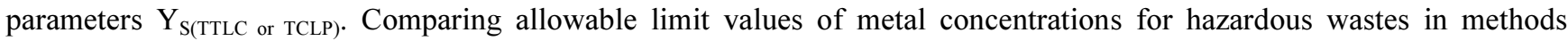
TCLP and TTLC, a 100-time difference in limit values can be noticed in most cases. Consequently, the calculated total toxicity may classify the tested waste material as non-toxic. The verified result may be interpreted by the impact on summary toxicity $\mathrm{Y}_{(\mathrm{TTLC})}$ of the individual metals for which the determined concentrations exceed allowable criteria limits. Better compliance with toxicity assessment on the basis of concentrations of leachable metals of the analyzed waste material is obtained for the results from the TCLP procedure (the classification of wastes based on $\mathrm{Y}_{(\mathrm{TCLP})}$ and $\mathrm{Y}_{\mathrm{S}(\mathrm{TCLP})}$ (Table 2).

Table 2. Determination and verification of toxicity for mobile telephones in compliance with the criteria of TTLC and TCLP based on minimum, average and maximum concentration values taken from the analytical data contained in the study [7]

\begin{tabular}{|c|c|c|c|c|c|c|}
\hline \multirow{4}{*}{$\begin{array}{l}\text { Metal }\left(M_{(\mathrm{n})}\right) \\
\mathrm{Y}_{\mathrm{SL}(\mathrm{TTLC}) \text { or (TCLP), }} \\
\mathrm{Y}_{(\mathrm{TTLC}) \text { or (TCLP) }} \\
\mathrm{Y}_{\mathrm{S}(\mathrm{TTLC}) \text { or (TCLP) }}\end{array}$} & \multicolumn{6}{|c|}{ Concentration $\left[\mathrm{mg} \cdot \mathrm{kg}^{-1}\right]$} \\
\hline & \multicolumn{2}{|l|}{$\min$} & \multicolumn{2}{|l|}{$\max$} & \multicolumn{2}{|l|}{ average } \\
\hline & TTLC $\left[\mathrm{mg} \cdot \mathrm{kg}^{-}\right.$ & TCLP $\left[\mathrm{mg} \cdot \mathrm{L}^{-}\right.$ & TTLC & TCLP $\left[\mathrm{mg} \cdot \mathrm{L}^{-}\right.$ & TTLC $\left[\mathrm{mg} \cdot \mathrm{kg}^{-}\right.$ & TCLP $\left[\mathrm{mg} \cdot \mathrm{L}^{-}\right.$ \\
\hline & & & {$\left[\mathrm{mg} \cdot \mathrm{kg}^{-1}\right]$} & & & \\
\hline Silver (Ag) & 9.28 & 0.0 & 177 & 0.010 & 65.9 & 0.006 \\
\hline Arsenic (As) & 20.1 & 0.056 & 60.0 & 0.067 & 36.1 & 0.062 \\
\hline Barium (Ba) & 1410 & 1.46 & 9260 & 2.88 & 5383 & 2.33 \\
\hline Cadmium (Cd) & 2.67 & 0.0006 & 3.4 & 0.006 & 2.93 & 0.004 \\
\hline Cobalt (Co) & 72.0 & n.d. & 460 & n.d. & 241.3 & n.d. \\
\hline Chromium (Cr) & 253 & 0.04 & 2330 & 0.13 & 958 & 0.07 \\
\hline Copper $(\mathrm{Cu})$ & 186000 & n.d. & 224000 & n.d. & 203000 & n.d. \\
\hline Mercury (Hg) & 0.37 & 0 & 1.7 & 0.010 & 0.79 & 0.006 \\
\hline Nickel (Ni) & 6340 & n.d. & 11200 & n.d. & 9247 & n.d. \\
\hline Lead $(\mathrm{Pb})$ & 8220 & 38.2 & 11600 & 147.0 & 10140 & 87.4 \\
\hline Selenium (Se) & 4.81 & 0.073 & 6.9 & 0.12 & 5.9 & 0.093 \\
\hline Zinc (Zn) & 8820 & n.d. & 12800 & n.d. & 11007 & n.d. \\
\hline \multicolumn{7}{|c|}{ Toxicity (calculated according to criteria equation (1)) } \\
\hline $\mathrm{Y}_{\mathrm{SL}(\mathrm{TTLC})}$ or $\mathrm{Y}_{\mathrm{SL}(\mathrm{TCLP})}$ & $\begin{array}{l}32220 \\
\left.(14720)^{b}\right)\end{array}$ & 122.2 & $\begin{array}{l}32220 \\
(14720)^{b)}\end{array}$ & 122.2 & $\begin{array}{l}32220 \\
(14720)^{b)}\end{array}$ & 122.2 \\
\hline $\mathrm{Y}_{(\mathrm{TTLC})}$ or $\mathrm{Y}_{(\mathrm{TCLP})}$ & $\begin{array}{l}16925 \\
(1560)^{\mathrm{b})}\end{array}$ & 2.76 & $\begin{array}{l}23595 \\
(7483)^{b)}\end{array}$ & 8.38 & $\begin{array}{l}20154(4512) \\
\text { b) }\end{array}$ & 5.49 \\
\hline Classification based & NT & NT & NT & NT & NT & NT \\
\hline on $Y_{(\mathrm{TTLC})}$ and $\mathrm{Y}_{(\mathrm{TCLP})}$ & $(\mathrm{NT})$ & & (NT) & & (NT) & \\
\hline $\mathrm{Y}_{\mathrm{S}(\mathrm{TTLC})}$ or $\mathrm{Y}_{\mathrm{S}(\mathrm{TCLP})}$ & $\begin{array}{l}211152 \\
(9920)^{b)}\end{array}$ & 39.83 & $\begin{array}{l}271899 \\
(23439)^{b)}\end{array}$ & 150.22 & $\begin{array}{l}240088 \\
(16593)^{b)}\end{array}$ & 89.97 \\
\hline Classification based & $\mathrm{T}$ & NT & $\mathrm{T}$ & $\mathrm{T}$ & $\mathrm{T}$ & NT \\
\hline on $\mathrm{Y}_{\mathrm{S}(\mathrm{TTLC})}$ and $\mathrm{Y}_{\mathrm{S}(\mathrm{TCLP})}{ }^{\mathrm{c})}$ & (NT) & & $(\mathrm{T})$ & & $(\mathrm{T})$ & \\
\hline
\end{tabular}

where: ${ }^{\text {a) }}$ n.d. - not detected analytical data; ${ }^{\text {b) }}$ the brackets show the values of $\mathrm{Y}_{\mathrm{SL}}, \mathrm{Y}$ and $\mathrm{Y}_{\mathrm{S}}$ without the concentrations of $\mathrm{Co}$, Cu, Ni and $\mathrm{Zn}$ to compare the criteria of toxicity; ${ }^{c)}$ the classification of waste material: NT - non-toxic and T - toxic.

Figure 1 presents the calculations for total toxicity of waste mobile phones on the basis of determined concentrations of four metals $(\mathrm{Ag}, \mathrm{Cd}, \mathrm{Cu}$ and $\mathrm{Pb}$ ) in accordance with TTLC procedure (analytical data taken from the study by Nnorom and Osibanjo [13]). For such a small number of metals, the determined toxicity and its verification are convergent, classifying the analyzed wastes as toxic. In order to compare, Figure 1 only includes the concentrations of these metals and parameters $\mathrm{Y}_{\text {(TTLC) }}, \mathrm{Y}_{\mathrm{SL} \text { (TTLC) }}, \mathrm{Y}_{\mathrm{S} \text { (TTLC) }}$ from the study [7]. Figure 2 shows values for the total toxicity calculation if the other metals (As, $\mathrm{Ba}, \mathrm{Cr}, \mathrm{Co}, \mathrm{Hg}, \mathrm{Ni}, \mathrm{Se}, \mathrm{Zn}$ plus to $\mathrm{Ag}, \mathrm{Cd}, \mathrm{Cu}, \mathrm{Pb}$ ) from the cited source of study [7] were used to estimate total toxicity. The difference between the classification methods based on $\mathrm{Y}_{(\mathrm{TTLC})}$ can be explained by smaller values of the coefficients $(\mathrm{a}-\mathrm{n})$ for equation (1) when toxicity is assessed for all metals.

Calculations for Figures 1 and 2 include the parameters for two metals exceeding threshold concentrations in TTLC procedure: copper $(\mathrm{Cu})$ and lead $(\mathrm{Pb})$, and Figure 3 includes respectively: cobalt $(\mathrm{Co})$ and nickel $(\mathrm{Ni})$. The presence of these metals (among the 4 analyzed ones) of concentrations higher then their limit levels unambiguously assesses the waste material as toxic in accordance with the TTLC criteria . On this basis, the rechargeable battery electrode (RBE) is classified as toxic $\left(\mathrm{Y}_{\text {(TTLC) }}\right.$ and $\mathrm{Y}_{\mathrm{S}(\mathrm{TTLC})}>\mathrm{Y}_{\mathrm{SL} \text { (TTLC) }}$ ) and the printed wiring board (PWB), respectively, as non-toxic (Y $\mathrm{Y}_{\text {(TTLC) }}$ and $\mathrm{Y}_{\mathrm{S}(\mathrm{TTLC})}<\mathrm{Y}_{\mathrm{SL}(\mathrm{TTLC})}$ ) (Figure 3). The classifications of waste mobile telephones made on the basis of parameters $\mathrm{Y}_{(\mathrm{TTLC})}$ and $\mathrm{Y}_{\mathrm{S}(\mathrm{TTLC})}$ qualify them to the same category. 


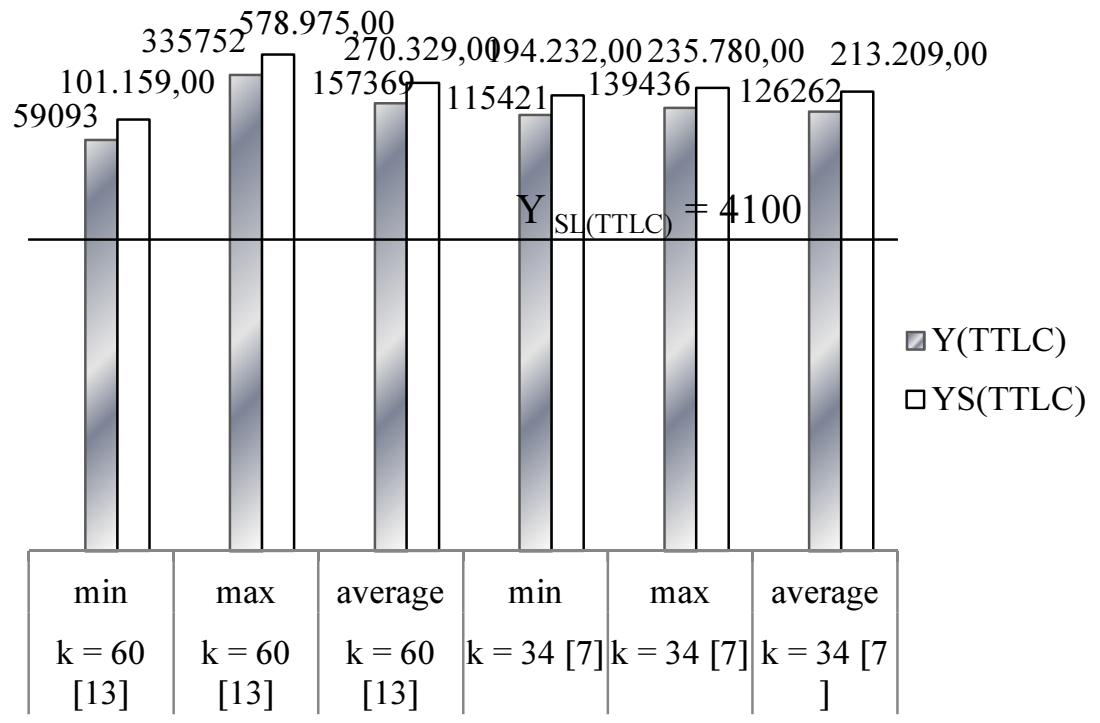

Fig. 1. Determination $\left(\mathrm{Y}_{(\mathrm{TTLC})}\right)$ and verification $\left(\mathrm{Y}_{\mathrm{S}(\mathrm{TTLC})}\right)$ of toxicity for mobile telephones in compliance with the criteria of TTLC ( $\left.\mathrm{Y}_{\mathrm{SL}(\mathrm{TTLC})}\right)$ based on minimum, average and maximum concentration values taken from the analytical data (only for $\mathrm{Ag}, \mathrm{Cd}, \mathrm{Cu}$ and $\mathrm{Pb}$ ) contained in studies $[7,13]$

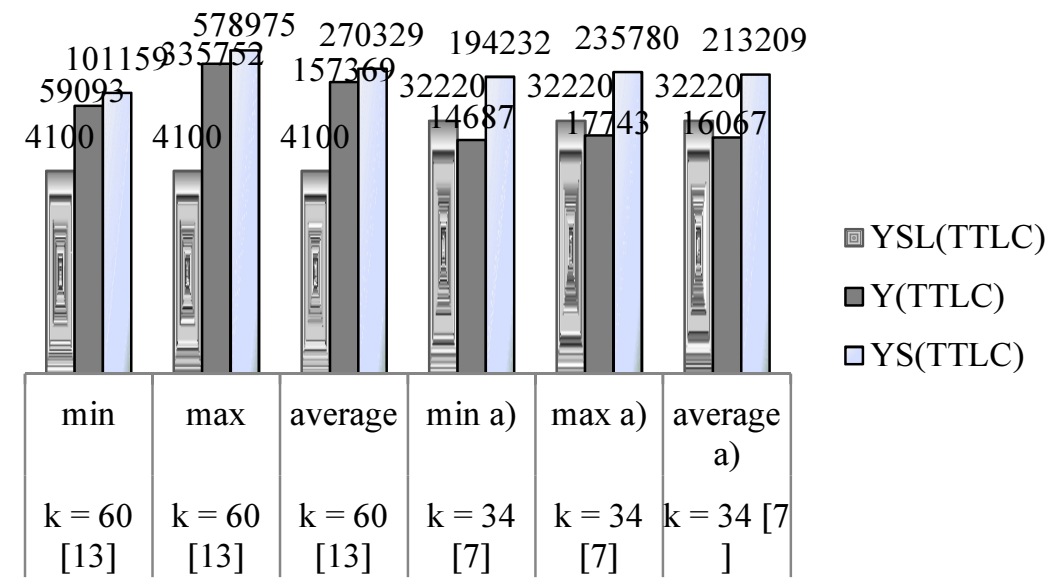

Fig. 2. Comparison of calculated $\left(\mathrm{Y}_{(\mathrm{TTLC})}\right)$ and verified $\left(\mathrm{Y}_{\mathrm{S}(\mathrm{TTLC})}\right)$ total toxicity for the literature data $[7,13]$. Where: $\mathrm{k}$ - the number of analyzed waste samples; a) - when other metals (As, $\mathrm{Ba}, \mathrm{Cr}, \mathrm{Co}, \mathrm{Hg}, \mathrm{Ni}, \mathrm{Se}$, $\mathrm{Zn}$ plus to $\mathrm{Ag}, \mathrm{Cd}, \mathrm{Cu}, \mathrm{Pb}$ ) from the cited source [7] were used to estimate total toxicity

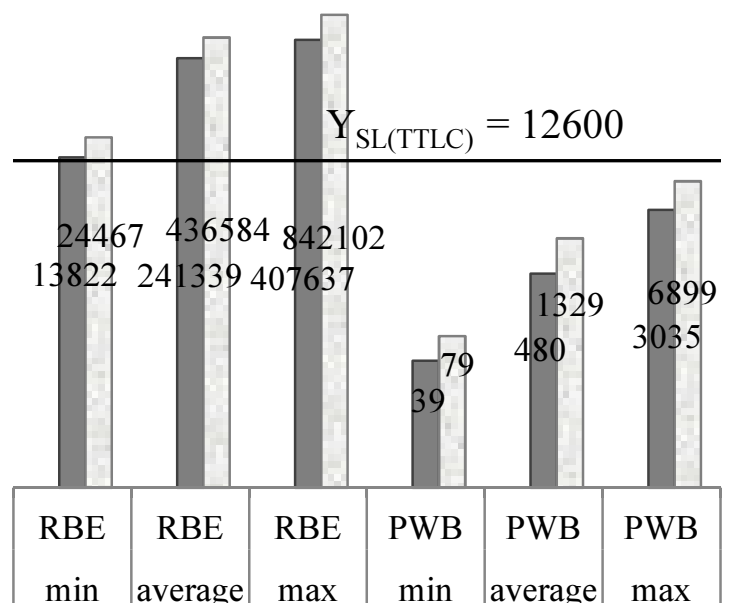

Fig. 3. Determination $\left(\mathrm{Y}_{(\mathrm{TTLC})}\right)$ and verification $\left(\mathrm{Y}_{\mathrm{S}(\mathrm{TTLC})}\right)$ of toxicity for the waste rechargeable battery electrode (RBE) and the printed wiring board (PWB) of mobile phones, in which minimum, average and maximum metal concentrations were determined in compliance with TTLC procedure based on the data taken from the study [12]. 


\section{Conclusion}

This study presents the parameters corresponding to potentially bioavailable pools to make the assessment of waste materials on the basis of known metal concentrations determined for exemplary waste material in accordance with the TTLC and TCLP procedures. As it is shown in tabular lists of values for the parameters: $Y_{(T T L C \text { or TCLP) }}$ and $Y_{\text {S(TTLC or TCLP), in }}$ the assessments based on actual metal concentrations, the non-exceedance of the permissible TTLC limit of one parameter ( $\mathrm{Cr}$ or $\mathrm{Pb}$ - determined parallelly) can be ambiguous as regards both the assessment of the calculated toxicity $\mathrm{Y}$ according to equation (1) and the assessment of verification $Y_{S}$. It should be noticed that the presented waste toxicity issue that takes into account the total and leached concentrations does not include possible effects of antagonism and synergisms, specific to a given component of the environment that may affect the actual level of toxicity in relation to the specific forms of biocenosis. Assessing the total toxicity of wastes on the basis of metals contained or leached from them, it is initially allowable to consider a sum of the individual ones, especially those determined in compliance with TTLC procedure, but in the next, more complex toxicological approach, the potential synergistic and/or antagonistic effects should be taken into account.

\section{References}

[1] Wellman, D. E.; Reid, D. A.; Ulery, A. L. 1999. Elevated soil arsenic levels at a former crude oil storage facility-assessment, remediation, and possible sources, Soil and Sediment Contamination 8(3): 329-341. http://dx.doi.org/10.1080/10588339991339360

[2] Kang, D. H. P.; Chen, M.; Ogunseitan, O. A. 2013. Potential environmental and human health impacts of rechargeable lithium batteries in electronic waste, Environmental Science and Technology 47(10): 5495-5503. http://dx.doi.org/10.1021/es400614y

[3] Macias, F.; Caraballo, M. A.; Nieto, J. M. 2012. Environmental assessment and management of metal-rich wastes generated in acid mine drainage passive remediation systems, Journal of Hazardous Materials 229-230: 107-114. http://dx.doi.org/10.1016/j.jhazmat.2012.05.080

[4] Ivan Diaz-Loya, E.; Allouche, E.N.; Eklund, S.; Joshi, A.R.; Kupwade-Patil, K. 2012. Toxicity mitigation and solidification of municipal solid waste incinerator fly ash using alkaline activated coal ash, Waste Management 32(8): 1521-1527. http://dx.doi.org/10.1016/j.wasman.2012.03.030

[5] Lopes, M.H.; Freire, M.; Galhetas, M.; Gulyurtlu, I.; Cabrita, I. 2009. Leachability of automotive shredder residues burned in a fluidized bed system, Waste Management 29(5): 1760-1765. http://dx.doi.org/10.1016/j.wasman.2008.11.005

[6] Komilis, D.; Tataki, V.; Tsakmakis, T. 2013. Leaching of heavy metals from personal computer components: comparison of TCLP with a European Leaching Test, Journal of Environmental Engineering 139(11): 1375-1381. http://dx.doi.org/10.1061/(ASCE)EE.1943-7870.0000752

[7] Lincoln, J. D.; Ogunseitan, O. A.; Shapiro, A. A.; Saphores, J. M. 2007. Leaching assessments of hazardous materials in cellular telephones, Environmental Science and Technology 41(7): 2572-2578. http://dx.doi.org/10.1021/es0610479

[8] Nnorom, I.C.; Osibanjo, O. 2009. Toxicity characterization of waste mobile phone plastics, Journal of Hazardous Materials 161(1): 183-188 http://dx.doi.org/10.1016/j.jhazmat.2008.03.067

[9] Li, Y.; Richardson, J. B.; Niu, X.; Jackson, O. J.; Laster, J. D.; Walker, A. K. 2009. Dynamic leaching test of personal computer components, Journal of Hazardous Materials 171(1-3): 1058-1065. http://dx.doi.org/10.1016/j.jhazmat.2009.06.113

[10] Rauckyte, T. 2011. Mathematical modelling for parametric assessment of general toxicity of wastes containing metals, in Proc. of the 8th International Conference Environmental Engineering, Vilnius, Lithuania, vol.1 Environmental Protection, 331-336.

[11] Rauckyte-Żak, T. 2011. Attempts of mathematical modelling to access general toxicity of metal containing wastes, in Proceedings of ECOpole 5(1): 97-101.

[12] Nnorom, I.C.; Osibanjo, O. 2009. Heavy metal characterization of waste portable rechargeable batteries used in mobile phones, International Journal of Environmental Science and Technology 6(4): 641-650. http://dx.doi.org/10.1007/BF03326105

[13] Nnorom, I.C.; Osibanjo, O. 2011. Determination of metals in printed wiring boards of waste mobile phones, Toxicological and Environmental Chemistry 93(8): 1557-1571. http://dx.doi.org/10.1080/02772248.2011.593519

[14] TTLC/STLC/TCLP Limit Table - Forensic Analytical Laboratories, Inc. Online: www.falaboratories.com/documents/lead_limits.pdf.

[15] Ernst, T.; Popp, R.; van Eldik, R.2000. Quantification of heavy metals for the recycling of waste plastics from electrotechnical applications, Talanta 53: 347-357. http://dx. doi.org/10.1016/S0039-9140(00)00491-4

[16] Schrijver, I.; Aramendia, M.; Vincze, L.; Resano, M.; Dumoulin, A.; Vanhaecke, F. 2007. Comparison of atomic absorption, mass and X-ray spectrometry techniques using dissolution-based and solid sampling methods for the determination of silver in polymeric samples, Spectrochimica Acta Part B 62: 1185-1194. http://dx.doi.org/10.1016/j.sab.2007.09.003

[17] Schrijver, I.; Aramendia, M.; Resano, M.; Dumoulin, A.; Vanhaecke, F. 2008. Novel strategies for rapid trace element analysis of polyamide by graphite furnace atomic absorption spectrometry and inductively coupled plasma mass spectrometry. Dissolution in an organic solvent versus direct solid sampling approaches, Journal of Analytical Atomic Spectrometry 23: 500-507. http://dx.doi.org/10.1039/b717257e

[18] Resano, M.; Briceño, J.; Belarra, M.A. 2009. Direct determination of $\mathrm{Hg}$ in polymers by solid sampling-graphite furnace atomic absorption spectrometry: a comparison of the performance of line source and continuum source instrumentation, Spectrochimica Acta Part B 64: 520-529. http://dx.doi.org/10.1016/j.sab.2009.03.017

[19] Rühl, W.J. 1985. Cadmium in polymers - product control in the automobile industry, Fresenius' Journal of Analytical Chemistry 322: 710-712. http://dx.doi.org/10.1007/BF00490546

[20] Belarra, M.A.; Lavilla, I.; Anzano, J.M.; Castillo, J.R. 1992. Rapid determination of lead by analysis of solid samples using graphite furnace atomic absorption spectrometry, Journal of Analytical Atomic Spectrometry 7: 1075-1078. http://dx.doi.org/10.1039/ja9920701075

[21] Duarte, A.T., Dessuy, M.B., Silva, M.M., Vale, M.G.R., Welz, B. 2010. Determination of cadmium and lead in plastic material from waste electronic equipment using solid sampling graphite furnace atomic absorption spectrometry, Microchemical Journal 96(1): 102-107. http://dx.doi.org/10.1016/j.microc.2010.02.008

[22] Diemer, J.; Heumann, K.G. 2000. Development of an ICP-IDMS method for accurate routine analyses of toxic heavy metals in polyolefins and comparison with results by TI-IDMS, Fresenius' Journal of Analytical Chemistry 368: 103-108. http://dx.doi.org/10.1007/s002160000469

[23] Wolksa, J. 2005. Safeguarding the environment - XRF analysis of heavy metals in polyethylene, Plastics, Additives and Compounding 7: 36-39. http://dx.doi.org/10.1016/S1464-391X(05)00334-X

[24] Bichinho, K.; Pires, G.P.; Stedile, F.C.; dos Santos, J.H.Z.; Wolf, C.R. 2005. Determination of catalyst metal residues in polymers by X-ray fluorescence, Spectrochimica Acta Part B 60: 599-604. http://dx.doi.org/10.1016/j.sab.2004.11.012 
[25] Santos, M.C.; Nóbreg,a J.A.; Baccana, N.; Cadore, S. 2010. Determination of toxic elements in plastics from waste electrical and electronic equipment by slurry sampling electrothermal atomic absorption spectrometry, Talanta 81 : 1781-1787. http://dx.doi.org/10.1016/j.talanta.2010.03.038

[26] Santos, M.C.; Nóbrega, J.A.; Cadore, S. 2011. Determination of Cd, Cr, Hg and Pb in plastics from waste electrical and electronic equipment by inductively coupled plasma mass spectrometry with collision - reaction interface technology, Journal of Hazardous Materials 190(1-3): 833-839. http://dx.doi.org/10.1016/j.jhazmat.2011.04.004

[27] Dimitrakakis, E.; Janz, A.; Bilitewski, B.; Gidarakos, E. 2009. Determination of heavy metals and halogens in plastics from electric and electronic waste, Waste Management 29(10): 2700-2706. http://dx.doi.org/10.1016/j.wasman.2009.05.020

[28] Delmas, F.; Villaescusa, I.; Woo, N.Y.S.; Soleilhavoup, J.P.; Murat, J.C. 2000. Cellular method for evaluation of noxiousness of inorganic pollutants in industrial wastes: calculation of a safety index for monitoring sludge discharge, Ecotoxicology and Environmental Safety 45: $260-265$. http://dx.doi.org/10.1006/eesa.1999.1876 